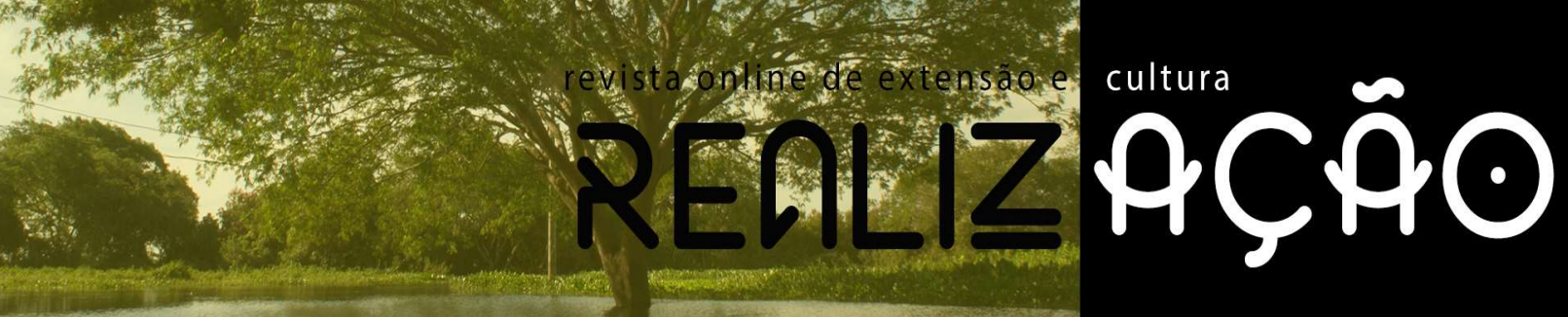

\title{
Sustainable rabbit production in rural settlements
}

\section{Produção sustentável de coelhos em assentamentos rurais}

DOI

10.30612/re-ufgd.v6i12.10840

\author{
Janaina Tayna Silva \\ Orlando Filipe Costa Marques \\ Nara Graciele Sales de Lima \\ Andrea Maria de Araujo Gabriel \\ Euclides Reutter de Oliveira \\ Jefferson Rodrigues Gandra \\ Helen Chaves Henning \\ Natalie Ferreira Neves \\ Hellen Felicidade Durães \\ Murillo Martins Lima \\ Jéssica Castilho de Lima
}

Recebido em: 16/12/2019 - Aceito em 17/12/2019

\begin{abstract}
The concern with sustainable productive activities is emerging, where we seek activities that simultaneously improve the living conditions of the populations and conserve the environment. Thus the rabbit can be considered as a strategic animal and the rabbit culture as a sustainable productive activity. From this perspective, the creation of rabbits in groups already formed in the community of settlers in Itamarati, Eldorado, Cabeceira do Iguatemi and Mutum, belonging to the municipalities of Ponta Porã, Sidrolândia, Paranhos and Alvorada do Sul, respectively, all in Mato Grosso Sul do These groups develop horticulture based on the techniques of organic production, where there are leftovers of vegetables and these surpluses were used to supply part of the rabbit's feed and thus develop a productive activity that provided income generation and protein source, allowing improvement in condition of families and especially group autonomy. In this context we aimed to describe the different types of infrastructure used as shelter for the animals in the creations in the settlements mentioned above. From the observations made in each community group, it was observed that the rabbit presented itself as an animal of importance for local sustainable development. The facilities where they were raised are rustic, designed by the producer himself and made with material present on the property, but with criterion taking into account the welfare of the animal.
\end{abstract}

Keywords: Family Farming, Cuniculture, Source of income, Installation.

Resumo - A preocupação com atividades produtivas sustentáveis é crescente, onde se busca por atividades que simultaneamente melhorem a condição de vida das populações e conservem o meio ambiente. Neste contexto, o coelho pode ser considerado como animal estratégico e a cunicultura como atividade produtiva sustentável. Sob esta perspectiva foi incentivada a criação de coelhos em grupos já formados na comunidade de assentados no Itamarati, Eldorado, Cabeceira do Iguatemi e Mutum, pertencente aos municípios de Ponta Porã, Sidrolândia, Paranhos e Alvorada do Sul, no estado de Mato Grosso do Sul. Estes grupos desenvolvem horticultura com base nas técnicas da produção orgânica, onde existem sobras de hortaliças e estes excedentes foram usados para suprir 
parte da alimentação do coelho e assim desenvolver uma atividade produtiva que propiciou geração de renda e fonte de proteína, permitindo melhoria na condição das famílias e, especialmente, autonomia dos grupos. Objetivou-se descrever os diferentes tipos de infraestrutura utilizados como abrigo para os animas nas criações dos assentamentos acima citados. Observou-se que o coelho se apresentou como um animal de importância para o desenvolvimento sustentável local e as instalações rústicas projetadas pelo próprio produtor e confeccionadas com material presente na propriedade demonstrou-se eficientes para produção dos coelhos.

Palavras Chaves: Produtores Familiares, Cunicultura, Instalações.

\section{Introduction}

Rabbit growth is the branch of animal science that consists in the breeding and production of domestic rabbit. According to the purpose of each producer, breeding may be geared to meat, skin, fur, genetic improvement, laboratory animals or pet animals. Cuniculture also offers several by-products such as leather, ears, paws and tail, blood, brain, stools and even urine. Rabbit production has great productive potential in small farms due to features such as low space requirements and sophisticated facilities, as well as the possibility of using alternative foods in their feed, thus reducing production costs, producing quality meat for food and generating income through the sale of surplus production.

Rabbits, Oryctolagus cuniculus, are herbivorous, monogastric animals and can be growth in simple systems without requiring improved facilities and are generally not very demanding in handling. So when the production is not exactly industrial, but for own consumption or even for small sales, the farmerr can make a rabbit with relatively low initial cost. The facilities do not need to be sophisticated in order to provide the animals with a proper, well-ventilated environment without weathering.

This information is a positive point for rabbit production, since these animals feed on a wide variety of foods and can adapt to rustic farming structures, making it an attractive proposition, especially when the goal is to produce animal protein of quality (DE ALMEIDA and SACCO, 2012; LUKEFAHR, 2004).

According to Machado and Ferreira (2014), most rabbit production in Brazil is not considered commercial, being considered as a secondary activity, since the farmerss work with other activities such as livestock, and / or crop production, being these activities responsible for generating most of the household income.

Also in relation to the production of rabbits in Brazil, the fact that the country has some regions with production zones and climate suitable for production is shown. There are also 
references or incentives to family farming, promoting employability and generating income for families who choose this activity (BONAMIGO et al., 2015). However, the lack of proper facilities and technical guidance limits producers to produce animals correctly, in order to keep animals in a clean environment free from disease, parasites and comfort. In this context, it is important to count on the possibilities of rational creation of using materials available in the facilities of installations in order to achieve higher reproductive and productive rates, recovery of recycling and reduction of the use of inputs (FERREIRA et al. 2012).

Given the above, the objective of this work was to discuss about several types of rabbit housing used in settlements in the state of Mato Grosso do Sul.

\section{Material and Methods}

The rabbit hutches were implemented in groups already formed in the settlement communities of Itamarati, Areias, Eldorado, Cabeceira do Iguatemi and Mutum, belonging to the municipalities of Ponta Porã, Nioaque, Sidrolândia, Paranhos and Nova Alvorada do Sul, all in the state of Mato Grosso do Sul. These groups are organized for the production of vegetables based on organic production techniques.

During the implementation of the projects, which started in January 2017, male and female New Zealand or crossbred rabbits, weaned with an average age of 45 to 60 days, were donated to communities. The rabbits were housed in the premises of the Fazenda Experimental of Faculdade de Ciências Agrárias (FCA) of the Federal University of Grande Dourados (UFGD), located in Dourados - MS, latitude $22^{\circ} 14^{\prime} \mathrm{S}$, longitude $54^{\circ} 49^{\prime} \mathrm{W}$ and altitude $450 \mathrm{~m}$, where the animals were mated periodically to obtain results for distribution among the producers participating in the project.

After the installation of the animals in the settlements, the follow-up of the production was carried out during the monthly meetings, marked with the participants emphasizing the collective organization. Theoretical and practical orientations were conducted on the content involved in meat production, genetic improvement, production systems, facilities, reproductive management, food management, sanitary management and zootechnical control.

Like methods for building facilities were discussed among all participants, with bunny configurations to be used according to the materials available in each group of participants.

An evaluation of the activities with the participants discusses the results that were performed as actions produced, assessing the degree of satisfaction of the needs of the target 
audience, such as the use of garden waste. There was also an increase in the group's actions, which does not refer to the production and diversification of products, as well as income generation and the results that provided greater visibility in the group's performance in the management of productive enterprises in the rural settlement area and possible participation of young settlers in carrying out applicable activities in the daily creation manual.

\section{Results and discussion}

In the choice of facilities and equipment, the economic factor was taken into account in order to have low cost.

In the Itamarati settlement, the rabbit house was built at $1.20 \mathrm{~m}$ from the ground, with the sloping roof having a height of $1.00 \mathrm{~m}$ at the highest part and $0.60 \mathrm{~m}$ at the lowest part; It is $2.00 \mathrm{~m}$ wide and $3.00 \mathrm{~m}$ long, being divided, with the aid of a screen, in the middle, where in the front are housed two females and two nests and in the back, the male (Figure 1). Just below the floor, made of wood slats separated by $3 \mathrm{~cm}$ cracks, are housed the poultry that need to remain separated from the others. One side is masonry and the other three sides are roofed, and the front and one side have a $50 \mathrm{~cm}$ wooden roof protection. As a feeder a candy can was used and as a drinker a half-cut plastic gallon and a pan. In the part where the females were housed there are closed internal nests, made according to the recommended dimensions, $45 \mathrm{~cm}$ long, $30 \mathrm{~cm}$ wide and $15 \mathrm{~cm}$ high (FERREIRA et al., 2012).

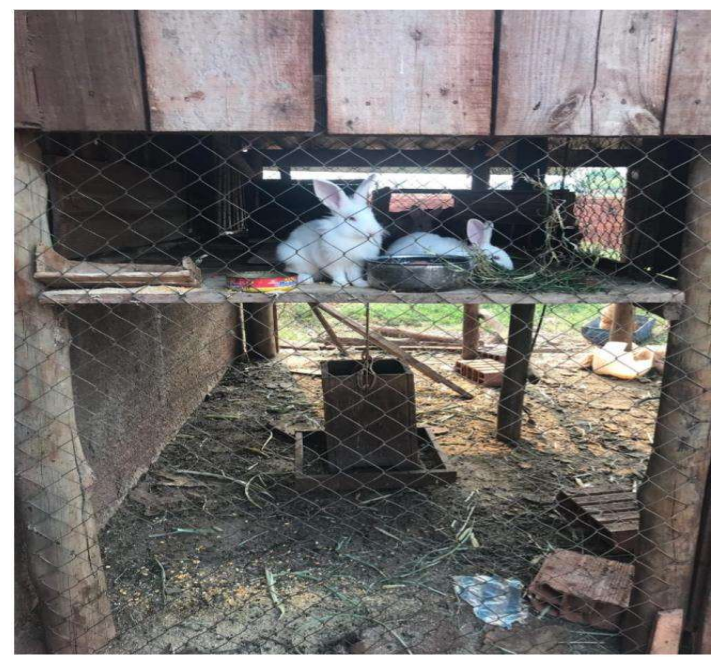

Figure 1. Anterior view of the rabbit in Itamarati Settlement, Ponta Porã, MS

In Areias settlement the rabbit house was built outdoors in the shade, it was built at 
$70 \mathrm{~cm}$ from the ground and surrounded with wood on the sides, floor and ceiling, with cracks between slats (Figure 02). The animals are kept individually in a space of $60 \mathrm{x} 60 \mathrm{~cm}$ with a height of $80 \mathrm{~cm}$. Access to the cage is from above, where there is a board that is displaced. As feeder and drinker, plastic pots are used. There is another similar facility where the male is housed but built 50 $\mathrm{cm}$ above the ground.

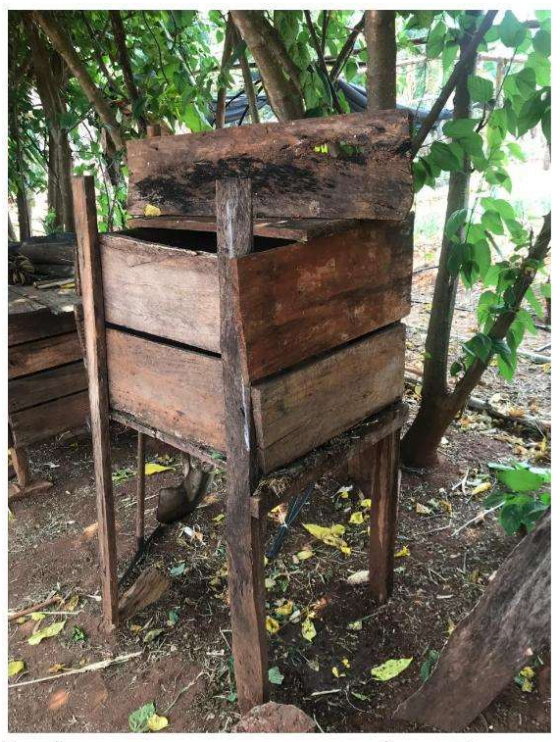

Figure 2. Rabbit in Areias settlement

In Eldorado settlement, three types of rabbit hen were built to divide the animals into lots, in a lot, identified as Lot A, the rabbit hen (Figure 03) is a collective where females and their offspring are raised and have a height, width and length equal to $1.14 \mathrm{~cm}, 74 \mathrm{~cm}$ and $1.70 \mathrm{~cm}$, respectively; It was built in a covered and suspended place at $50 \mathrm{~cm}$ from the ground, with the slatted floor, the front and back are tiled, but the sides were protected with plastic and the rear has a protection with height from the floor of $50 \mathrm{~cm}$; the door was made of wood slats and the plywood roof. The feeder and drinker are plastic pots and inside there is open type nest for the younger. The same description applies to the installation of the breeding male which is separated from the dies.

The second rabbit in batch B (Figure 03) is also collective for females and their young and is built directly on the floor. The front, back, side and roof structure were made of $3 / 8$ rebar with a spacing of $20 \mathrm{~cm}$ between them around which, including the roof, a screen was placed. The ceiling was also protected with fiber cement tiles. The dimensions of the structure are: $100 \mathrm{~cm}$ high, $120 \mathrm{~cm}$ long and $90 \mathrm{~cm}$ wide and the access is made by a $30 \mathrm{~cm}$ crack in the ceiling. The feeder used is a dish for tubular chicken feeders and a water cooker was used as a pan. The player is allocated individually in an installation as described above. 
In the creation of Lot $\mathrm{C}$ (Figure 03), both male and female rabbits are raised individually in wire cages, which are movable and stand on the grass, have dimensions of $60 \mathrm{x}$ $80 \mathrm{~cm}$ and the roof is protected with a tile of fiber cement. The feeder and drinker were made of plastic pots.

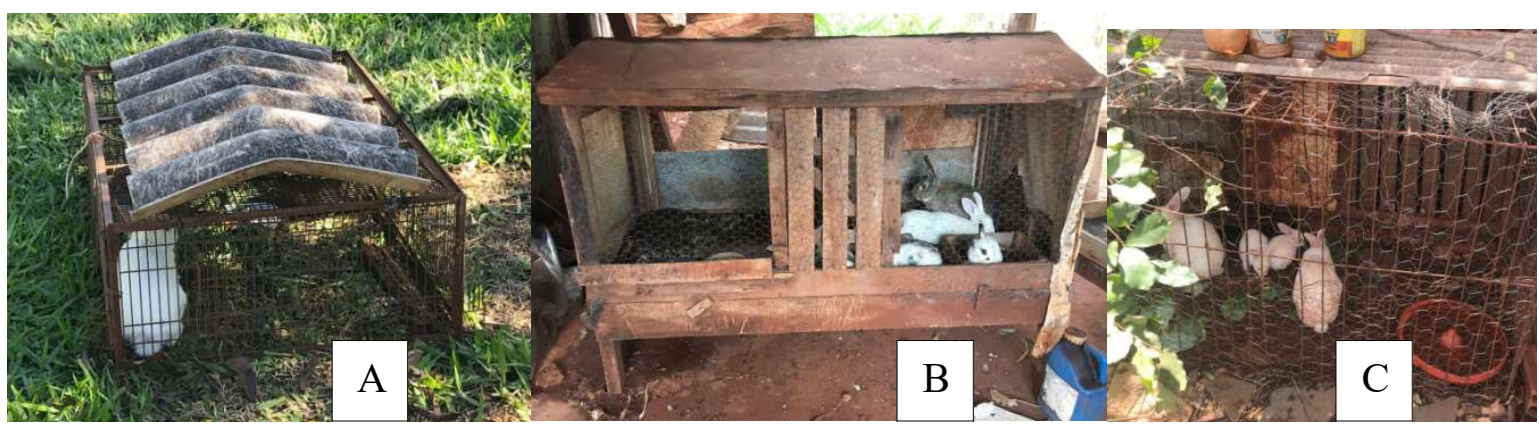

Figure 3. Rabbit in Areias settlement, Nioaque, $M S$

In the group of residents of Cabeceira settlement of the Iguatemi River, the rabbit hut was designed taking into account the animal category where adults are raised on the ground, in an area of $114 \times 208 \mathrm{~cm}$ and the pups remain in a suspended shelter with an area of $114 \times 220 \mathrm{~cm}$, both covered with fiber cement tile. The rabbit hut has shingles on one side and front, back and the other side were built with planks and leaving the ceiling there is a canvas that covers the screened parts and thus protects animals from the sun's rays. The area where the adult animals are located is surrounded by planks interspersed with fiber cement tile, the bottom and sides being $120 \mathrm{~cm}$ high and the front $70 \mathrm{~cm}$. The drinking fountains are pots and the feed is placed on a flat metal structure. In the shelter of pups there is cardboard protection and plywood placed on the floor as a platform for foot rest and also has PVC (Polyvinyl Chloride) pipe to enrich the environment, which will be very important for improving the quality of life of rabbits (MACHADO, 2019).

In Mutum settlement the production system adopted was free system, where the animals shelter gives access to two paddocks with dimensions of approximately $2.0 \mathrm{~m} \times 3.0$. This shelter is built with plywood sheets on its sides and covered with asbestos tiles and has the following measures: $2.0 \mathrm{~m}$ wide, $2.0 \mathrm{~m}$ high and $4.0 \mathrm{~m}$ long, being divided in half, as each half give access to a picket. The pickets are surrounded with bamboo-fixed canvas and covered with plastic tarpaulin that is attached to the ground through a row of French tiles (Figure 4). As a feeder a dish and tubular chicken feeders were used and the drinker used is clay pots. 


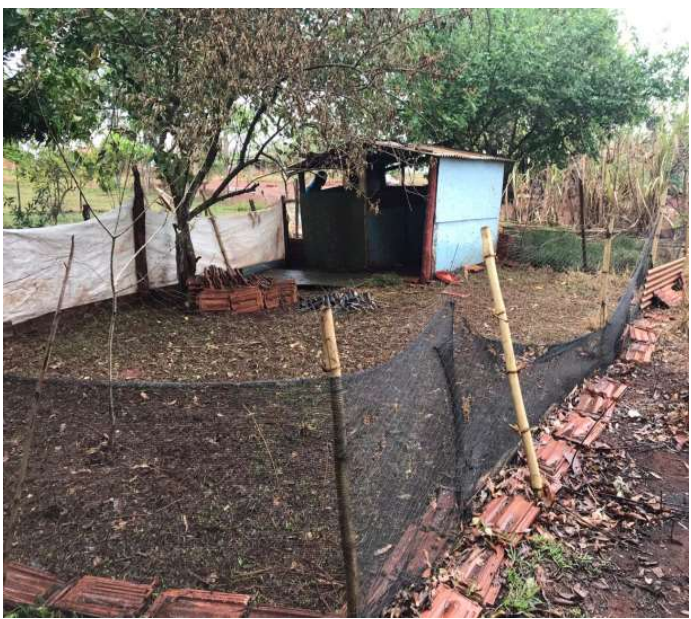

Figure 4. Rabbit in Mutum settlement, Nova Alvorada do Sul, MS

According to the results described above, some observations could be made, as the feeders used are easy to clean and decontaminate, but they are present inside the rabbit hutch and some do not have an edge to prevent losses preventing the animal from spilling the feed as recommended by Carvalho (2009). At the water cooler, water is available in sufficient quantity and quality to help with your digestive, reproductive and maintenance processes, as well as to control your body temperature. The water provided was fresh and wherever possible free of contamination, i.e. dust, feed dust, urine, feces (RIOS et al., 2011).

The nest, one of the main items in rabbit production, because it is the place where the birth takes place and where the pigs are in the first days of life, was observed only in the creation of the Itamarati Settlement, because the rabbits that had access to the ground they made their nests dug in the ground, since rabbits are known gregarious animals that dig galleries and have nocturnal habit (MOURA, 2002).

It can also be mentioned that rabbit production is of great social importance, as it can be developed in small space and, therefore, in small properties due to its potential for integration and complementarity with other activities of the producer. In this context, raising small animals can be a lucrative option for rural people, offering work for women, children and the elderly and as a source of protein that can be used for self-consumption or for marketing (MACHADO, 2012; OSENI, 2012).

\section{Conclusion}

The establishment of rustic rabbit hutches in the settlements was a viable alternative due to its low cost of implementation, and it was observed that the rabbit presented itself as an 
important animal for local sustainable development.

\section{Acknowledgment}

To the Conselho Nacional de Desenvolvimento Científico e Tecnológico (CNPq) and a Coordenação de Aperfeiçoamento de Pessoal de Nível Superior (CAPES) for the granting of the scholarship. Support from the Federal University of Grande Dourados, through the Pró-Reitoria de Extensão e Cultura (PROEX/UFGD); to the Centro Vocacional Tecnológico em Agroecologia e Produção Orgânica in Mato Grosso do Sul and to Núcleo de construção participativa do conhecimento em agroecologia e produção orgânica da UFGD.

\section{References}

BONAMIGO, A.; WINCK, C. A.; SEHNEM, S. Diagnóstico da produção e comércio cunícula no Estado de Santa Catarina. Revista Brasileira de Cunicultura, v. 7, n. 1, p. 09-33. 2015.

CARVALHO, R. C. Caracterização da produção cunícula nas regiões de Trás-os-Montes, Minho e Galiza. Dissertação-Mestrado em Engenharia Zootécnica, Universidades Trás-os-Montes e Alto Douro, 2009.

DE ALMEIDA, D. G.; SACCO, S. R. Estudo da viabilidade técnica e econômica para implantação da cunicultura em pequena propriedade rural. Revista Perspectiva em Gestão, Educação \& Tecnologia, v.1, n.1, p.1-9, 2012.

FERREIRA, W. M.; MACHADO, L. C.; JARUCHE, Y. G.; CARVALHO, G. G.; OLIVEIRA, C. E. Á.; SOUZA, J. A. S., CARRISSIMO, A. P. G. Manual prático de cunicultura. Bambuí: Associação Brasileira de Cunicultura, 2012.

LUKEFAHR S. Strategies for the development of small- and medium-cale rabbit farming in SouthEast Asia. Livestock Research for Rural Development. v.19, n. 9, p. 138. 2004.

MACHADO, L. C. Nota Técnica - Como enriquecer as gaiolas dos coelhos gastando pouco. 2019. MACHADO, L. C; FERREIRA, W. M. Sistema de produção da cunicultura. Revista Brasileira de Cunicultura, v. 6, n.1, 2014.

MOURA, B. B. Produção de coelhos. Emater, Rio de Janeiro 2002.

OSENI, S.O.Rabbit production in low-input systems in Africa: prospects, challenges and opportunities. In: 10 TH WORLD RABBIT CONGRESS, 10, 2012, Sharm El- Sheikh. Proceedings. Egito: World Rabbit Science Association, 2012.

RIOS, D. M. BARBOSA, L. E.; NEVES, M. V. B.; BARREIROS, T. N.; OLIVO, M. Manual de cunicultura. Trabalho de conclusão de curso, Universidade do Estado da Bahia, 2011. 